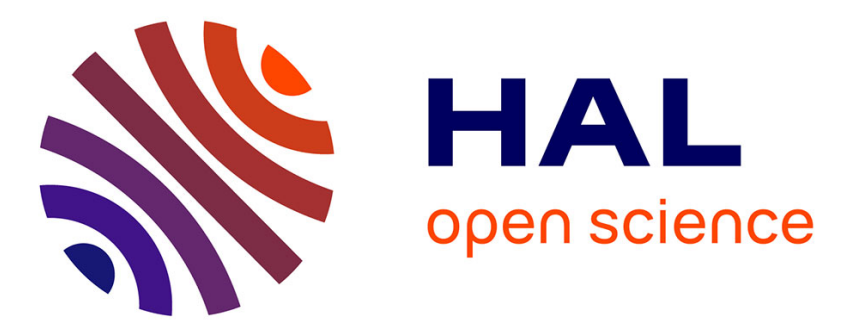

\title{
MORPHOMETRICAL CHANGES OF THE GROWTH PLATE AFTER A SINGLE DOSE HeNe LASER IRRADIATION IN WISTAR RAT
}

F. Sendra, J. Pastor, M. Labajos, E. Fernandez Vicioso, L. de La Peña, R. Ruiz

\section{To cite this version:}

F. Sendra, J. Pastor, M. Labajos, E. Fernandez Vicioso, L. de La Peña, et al.. MORPHOMETRICAL CHANGES OF THE GROWTH PLATE AFTER A SINGLE DOSE HeNe LASER IRRADIATION IN WISTAR RAT. Journal de Physique IV Proceedings, 1991, 01 (C7), pp.C7-245-C7-248. 10.1051/.jp4:1991762 . jpa-00251005

\section{HAL Id: jpa-00251005 https://hal.science/jpa-00251005}

Submitted on 1 Jan 1991

HAL is a multi-disciplinary open access archive for the deposit and dissemination of scientific research documents, whether they are published or not. The documents may come from teaching and research institutions in France or abroad, or from public or private research centers.
L'archive ouverte pluridisciplinaire HAL, est destinée au dépôt et à la diffusion de documents scientifiques de niveau recherche, publiés ou non, émanant des établissements d'enseignement et de recherche français ou étrangers, des laboratoires publics ou privés. 


\title{
MORPHOMETRICAL CHANGES OF THE GROWTH PLATE AFTER A SINGLE DOSE HeNe LASER IRRADIATION IN WISTAR RAT
}

\author{
F. SENDRA, J.M. PASTOR, M.T. LABAJOS, E. FERNANDEZ VICIOSO, L. de la PEÑA, \\ R. RUIZ and M. LABAJOS \\ Departamento de Radiologia y Fisioterapia, Facultad de Medicina, Universidad de Màtaga, \\ Campus Universitario de Teatinos, SP-29080 Màlaga, Spain
}

\begin{abstract}
We analyse the results in 60 wistar rats, divided in four groups: three of them were irradiated with Helium-Neon (He-Ne) laser in the proximal fibular growth plate, with the following energy densities: $3.6,5.4$, and $7.2 \mathrm{~J} / \mathrm{cm}^{2}$, and the fourth one, received no irradiation, as a control group. The results were collected 2,4 and 8 days after irradiation, for all groups, studying some morphological parameters like cell number, cell area, and depth of the proliferative and hypertrophiclayers of growth plate.

Theresults showed an increase of all parameters in the proliferative layer, particulary in the $7.2 \mathrm{~J} / \mathrm{cm}^{2} \mathrm{group}$, when analyzed after 8 days.

These results strongly suggest an stimulative effect of He-Ne laser on the growth plate. Higher energies and longer periods of time should be tested, trying to asses an increasing effect an its duration.
\end{abstract}

\section{DNTRODUCTION}

The bone has a temporal and specific zone for growth called "ephifisarian plate or growth plate". This zone is composed by several layers. Two of them, named proliferative and hypertrophic are the directly responsibles of the bone enlargement. Cell division is predominant in thefirst one, while cell maduration and degeneration are realized in the hypertrophic layer to prepare the cartilage for the asification. A functional equilibrium between both layers (proliferation vs. maduration) exists under normal conditions.

We based the present study on the principle of the stimulative effect of low power laser irradiation wich may contribute or interfere somehow to the changes in a so active zone as the growth plate. For this purpose we started a morphometrical analysis of the proximal fibular growth plate of rat, after having been someted to low power laser irradiation of Helium-Neon.

\section{MATERIALSAND METHODS}

This study has been realized in albine wistar rats with ages between 25 and 40 days (this is the main bone growth period for these animals). Totally we used sixty animals ( 42 females and 18 males). The averages of heigth and weigth were $63 \pm 6.8 \mathrm{~g}$ and $13.3 \pm 0.2 \mathrm{~cm}$, respectively.

The irradiation has been realized with a He-Ne laser of continuos emision, $6 \mathrm{~mW}$ output and $632.8 \mathrm{~nm}$ wavelength(redspectra).

We stablishedfour experimental groups of 15 animals each. Three of them were irradiated at 3.6, 5.4 and 7.2 
$\mathrm{J} / \mathrm{cm}^{2}$ respectively, and the fourth one received no irradiation as a control group. Afterwords, 5 animals of each group were sacrified within 2,4 and 8 days after irradiation.

In all cases, the experimentstook place between 9 and 12 a.m. and the controls suffered the same experimental conditions than the test groups. All the animals received anaesthesia with $10 \%$ chloral hydrate intraperithoneally, to have the same stress support. The skin fur of right knee was removed and after that, the proximal fibular ephifisis was irradiated. After 2, 4 and 8 days as explained before, in the experimental design, the animals were sacrified after perfusion with $10 \%$ formaldehide. The specimen was obteined after fibular proximal and femoral distal osteotomies. Themorphometrical analysis of the slides was performed with the digital image processing system Zeiss-KontronMop-Videoplan.

Three parameters were mesured: depth of the proliferative and hipertrophic layers, cell number per condrocyte column and cell area. Theresults werestatisticaly analyzed with the $T$ of Student function.

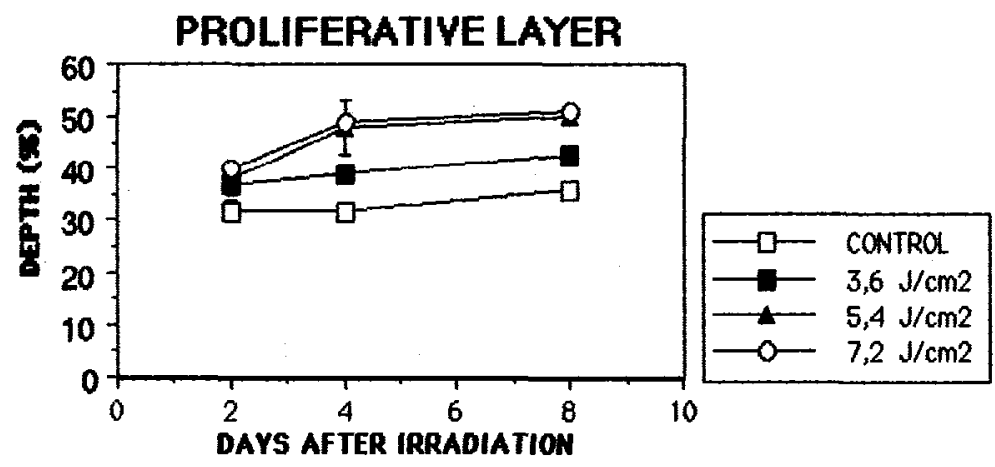

Fig.1. Depth of the proliferative layer measured at 2, 4 and 8 days after irradiation. Results are presented as percentage of the growth plate depth (mean $\pm \mathrm{SE}$ )

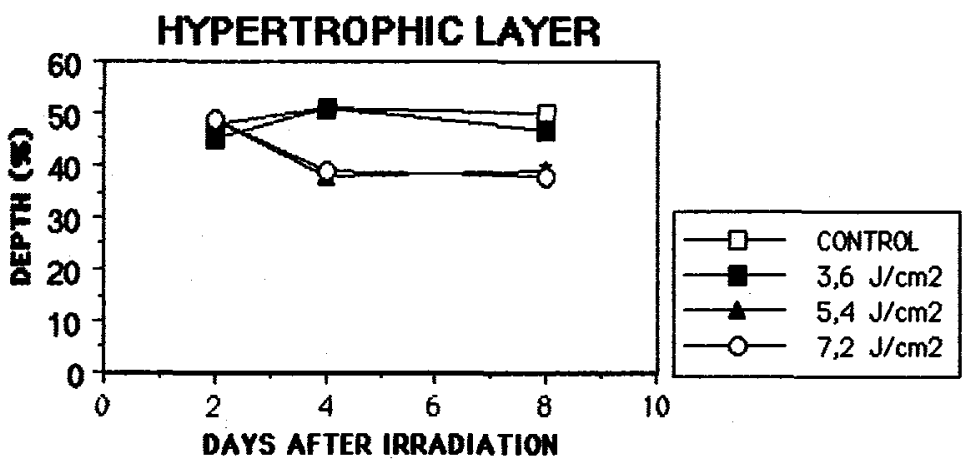

Fig.2. Depth of the hypertrophic layer measured at 2, 4 and 8 days after irradiation. Results are presented as percentage of the growth plate depth (mean \pm SE) 


\section{RESULTS}

While analysing the depth of the growth plate layers, we observed that there are no significant modifications within the control group values in the animals sacrified two days after irradiation. Nevertheless for the doses of 5.4 and $7.2 \mathrm{~J} / \mathrm{cm}^{2}$, we observerd an increase of the depth of the proliferative layer together with a decrease of the hypertrophiclayer. Theresults are shown in the figures 1 and 2 refered in relation to the total depth of the plate in percentages.

Thenumber of prolipherative cells per column significantly increases over the controls in all the animals when were sacrified 4 and 8 days postirradiation. This effect is slighly superior with doses of $7.2 \mathrm{~J} / \mathrm{cm}^{2}$. No effect was seen in animals sacrified 2 days afterirradiation (Fig.3).

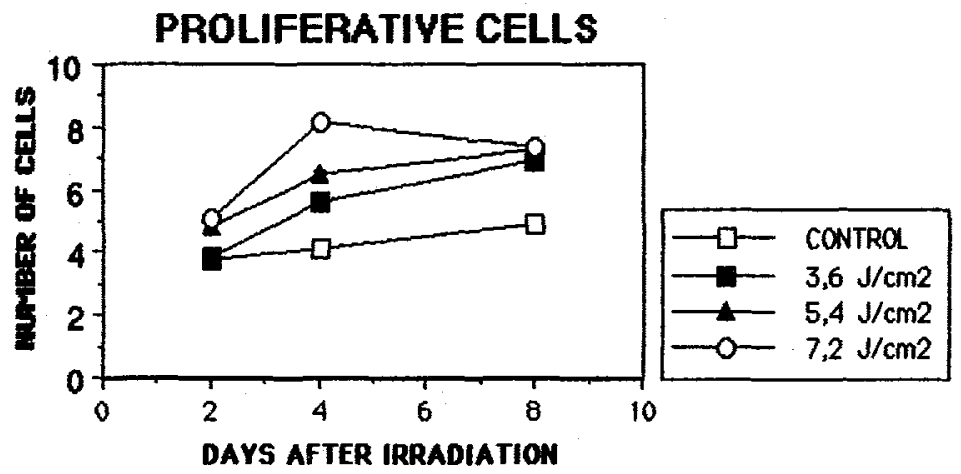

Fig. 3. Number of Proliferative cells per column of condrocytes (mean \pm SE) counted at 2,4 and 8 days after irradiation withdifferent doses

HYPERTROPHIC CELLS

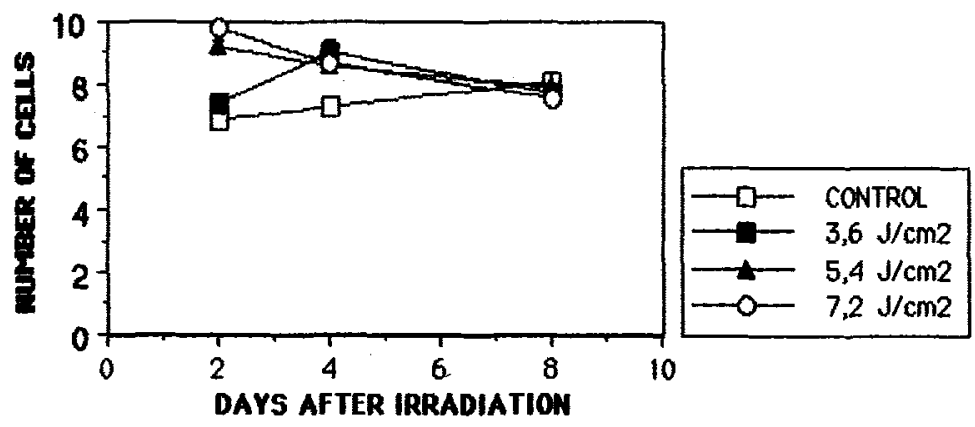

Fig.4. Number of Hypertrophic cells per column of condrocytes (mean \pm SE) counted at 2,4 and 8 days after irradiation with different doses

For the contrary, the number of hypertrophic cells suffered and increase with doses of 2.4 and $7.2 \mathrm{~J} / \mathrm{cm}^{2}$ in the animals sacrified at 2 days, returning to the control values after 4 and 8 days postirradiation (Fig.4). 
The proliferative cell area decreases significantly with doses of 5.4 and $7.2 \mathrm{~J} / \mathrm{cm}^{2}$, and specially after 8 days postirrradiation. In the hypertrophic layer no significant diferences was seen in the cell area at 2 and 4 days; nevertheless after 8 days postirradiation we could apreciate asignificantincrease on the cell size.

\section{DISCUSSION}

Analysing the results we can firtsly see a stimulous on the proliferative layer, in its depth and in the cell number by column, in the groups sacrified at 4 and 8 days, respect the controls. The absence of response in the 2 days group can be due to the fact that it has not been enough time to let the cell divides Time request for cells division is $52 \mathrm{~h}$. (1). This stimulative effect is more evident with doses of 5.4 and $7.2 \mathrm{~J} / \mathrm{cm}^{2}$, and could be due to an increase of the cartilage vascularization, whichin other words is equivalent to astimulation of condroblastic capacity (2).

The high increase of the proliferative layer corresponds to a high decrease of the hypertrophic layer with the same doses, and the same days postirradiation mencioned before (Fig 1 and 2). This results strongly suggest an equilibrium between theproduction and maduration of the cartilage (3).

While the number of proliferative cells per column increases at 4 and 8 days postirradiation, the number of hypertrophic cells increases at 2 days and decreases progresively to the control group values at 8 days (Fig. 3 and 4). This decreasing can be explained if we consider than the hypertrophic condrocytes have no division capacity and proceded from proliferative condrocytes (4). The results suggest an early stimulation of the proliferative to hypertrophic condrocyte transformation, followed by an increase in the cell divisions of the proliferative condrocytes. A decrease of the proliferative cell areas can be seen as a consequence of the increase of the cell division rithm (5), specially with doses of 5.4 and $7.2 \mathrm{~J} / \mathrm{cm}^{2}$ at 8 days postirradiation (Fig.5).

Hypertrophic layer cells, encharged of the growth plate degeneration and osification increase their size and volumein thehypertrophicphase. This explain the fact that the control group shows a increase of the cell size at 4 and 8 days (taking into account that this time suposes a considerable increase of the biological bone age of the rats). In the irradiated group this increase is produced over the control group values at doses of $7.2 \mathrm{~J} / \mathrm{cm}^{2}$.

\section{CONCLUSIONS}

He-Ne laser irradiation stimulates the proliferativelayer of the growth plate, increasing its depth and the number of cells per column. The increases of both parameters in the proliferative layer corresponds with a decrease of hypertrophic layer. These results are significant at doses of $5.4 \mathrm{~J} / \mathrm{cm}^{2}$, and specially at $7.2 \mathrm{~J} / \mathrm{cm}^{2}$. The values obtained in the group of $3.6 \mathrm{~J} / \mathrm{cm}^{2}$ were no significant. These results are more evident at 8 days postirradiation.

Higher energies and longer periods of time should be tested, trying to assess an increasing effect and its doration.

\section{REFERENCES}

1. HUNZINKER, EB. Pathol Inmunopathol Res. 7 (1988) 9-13.

2. TRELLLES, MA and MAYAYO, E. Laser Surg Med. 7 (1987) 36-45.

3. SVENSON ,O. La Kartidningen. 83 (1986) 2643-2646.

4. FARNUN, CE and WILSMAN, NJ. Anat Rec. 219 (1987) 221-232.

5. KARBOWSKI, A and CAMPS, L. Z Orthop. 123 (1985) $403-408$. 